\title{
ANALISIS KINERJA SEKOLAH DALAM MEMINGKATKAN MUTU PENDIDIKAN MELALUI AKREDITASI \\ (Studi Pada SMP Sekecamatan Saparua dan Saparua Timur)
}

\author{
Cynthia Lusye Sapulette \\ Fakultas Ilmu Pendidikan Kristen, IAKN Ambon \\ cyntialusye@gmail.com
}

\begin{abstract}
How does the school prepare to implement school accreditation, which starts with filling in the field of accreditation data "DIA"?, (2) are recommendations from the assessors who do the visitation of 8 Education standards?, (3) efforts made to ensure quality education, (4). What factors become a barrier to improving the quality of education through school accreditation?. The study uses a descriptive method of quality. Qualitatively, it indicates that (1) accreditation is essential to the quality of the school. There must be a working team in the school for the fulfillment of 8 SNP. Charging HIM Online as an early stage of school readiness for accreditation. (2) The Assessor recommendation helps the school to see its weakness, to be repaired to be even better. (3) The development of teachers capacity and education, the development of Sarpras, organizing the administration, focus on the development of students ' character to achieve achievement. Budget that focuses on school needs, engages in the midst of society, or engages the community in activities in the school. (4) Teachers are not motivated to perform their duties with the target time. Teachers are indifferent with existing developments, and do not want to improve their scientific skills. The senior teachers and almost retired, felt difficulties in Menyesuikan with the demands of the existing curriculum, all of which is a barrier in the process of achieving the quality of education in school. And the lack of budget becomes a barrier in supporting various work programs.
\end{abstract}

Key words: School performance, education quality, accreditation

\section{Pengantar}

Setiap sekolah di Indonesia berhak untuk meminta akreditasi atau siap untuk dilakukan akreditasi oleh Badan Akreditasi Sekolah secara periodik. Secara konsep, tujuan diselenggarakannya akreditasi sekolah/madrasah ialah (1) memberikan informasi tentang kelayakan sekolah/madrasah atau program kejuruan yang dilaksanakannya berdasarkan Standar Nasional Pendidikan; (2) memberikan pengakuan peringkat kelayakan; (3) memberikan rekomendasi tentang penjaminan mutu pendidikan kepada progam dan atau satuan pendidikan yang diakreditasi dan pihak terkait. Adapun hasil akreditasi sekolah diberi peringkat berdasarkan penilaian diri (instrumen akreditasi) oleh sekolah bersama tim penilai (assessor) dari Badan Akreditasi Nasional Sekolah/Madrasah (BAN-S/M) yang kemudian oleh Badan Akreditasi Nasional ditentukan sekolah tersebut.

Hasil akreditasi sekolah menunjukkan perbedaan kualifikasi yang dicapai oleh tiap-tiap sekolah yang mencakup delapan Standar Nasional Pendidikan, dimana kedelapan Standar Nasional Pendidikan itu diwadahi dalam Standar Pengelolaan Pendidikan. Mengingat Standar Pengelolaan Pendidikan adalah standar nasional pendidikan yang berkaitan dengan hal perencanaan, pelaksanaan dan pengawasan kegiatan pendidikan. Soedjono(2012) mengungkapkan faktanya penyelenggaraan akreditasi Sekolah/Madrasah saat ini menghadapi beberapa persoalan diantaranya (1) hasil akreditasi belum menggambarkan kondisi objektif sekolah; (2) hasil akreditasi belum menunjukkan indikator akuntabilitas; (3) hasil akreditasi sekolah belum dijadikan sebagai alat pembinaan, pengembangan dan peningkatan mutu pendidikan di sekolah; (4) peringkat hasil akreditasi belum menggambarkan kelayakan sekolah; dan (5) hasil akreditasi belum mampu memberikan rekomendasi tentang penjaminan mutu pendidikan.

Data awal ditemukan pada SMP Negeri 3 Saparua bahwa proses mempersiapkan akreditasi, menunjukan bahwa kepala sekolah, guru dan tenaga kependidikan masih merasa kesulitan dalam memenuhi kebutuhan pada standar penilaian. Waktu akreditasi semakin dekat, kepala sekolah dan guru mempersiapkannya sampai larut malam. Saat menyusun dokumen standar penilaian masih saja salah dalam penempatannya sehingga dinilai tidak konsisten. Sekolah sampai saat ini belum mampu meningkatkan status akreditasi dari B ke A, hal ini menunjukan bahwa sekolah mengalami kesulitan dalam menata pendidikan yang sesuai $8 \mathrm{SNP}$, suatu 
indikator dari keadaan pendidikan tentang upaya mutu dan kualitas pendidikan di sekolah.

Permasalahan terkait dengan proses dan pasca hasil akreditasi sekolah juga dapat ditemui pada SMP Negeri 4 Saparua, yang menunjukan problematika seperti berikut : proses persiapan akreditasi mengalami banyak persoalan yang terkait dengan pemenuhan 8 standar pendidikan. Untuk itu maka hasil akreditasi memposisikan sekolah ini pada sekolah dengan akreditasi C. dan sejak tahun 1990 sampai saat ini, sekolah ini belum pernah mengalami perubahan status akreditas menjadi baik (standar "B"). Suatu kenyataan yang perlu mendapatkan perhatian serius dari pihak sekolah untuk berupaya keras agar memperbaiki diri, mengupayakan dengan berbagai cara dan strategis untuk mencapai standar penilaian yang sesuai agar mendapatkan peningkatan akreditasi. Kenyataan ini menjadi menarik untuk diperluas dugaan awal untuk SMP lainnya khususnya yang berada pada Rayon atau Kecamatan Saparua, sehingga juga memberikan informasi yang lebih memadai terkait proses dan pasca hasil akreditasi sekolah sehingga diperoleh gambaran tentang bagaimana persiapan sekolah dalam menghadapi akreditasi, Upaya-upaya apa saja yang dilakukan untuk dapat menjamin mutu pendidikan yang berkualitas, Adanya atau tidaknya rekomendasi pasca akreditasi sekolah oleh Asesor BAN S/M, dan Faktor apa saja yang menjadi penghambat dalam meningkatkan mutu pendidikan melalui akreditasi sekolah.

Akreditasi salah satunya bertujuan untuk menjamin dan mengendalikan mutu pendidikan yang sesuai dengan Standar Nasional Pendidikan (SNP), dengan demikian Berdasarkan uraian di atas, maka judul "Analisis Kinerja Sekolah Dalam Meningkatkan Mutu Pendidikan Melalui Akreditasi Pada SMP Se Kecamatan Saparua Kabupaten Maluku Tengah" perlu untuk diangkat.

\section{Tinjauan Literatur}

\section{Akreditasi Sekolah/Madrasah}

Akreditasi adalah kegiatan penilaian kelayakan programdan/atau satuan pendidikan berdasarkan kriteria yang telah ditetapkan sebagaimana dinyatakan pada UU Nomor 20 Tahun 2003 tentang Sistem Pendidikan Nasional, pasal 1 ayat (22). Akreditasi sekolah/madrasah adalah proses penilaian secara komprehensif terhadap kelayakan satuan atau program pendidikan, yang hasilnya diwujudkan dalam bentuk pengakuan dan peringkat kelayakan dalam bentuk yang diterbitkan oleh suatu lembaga yang mandiri dan profesional. Sekolah/madrasah adalah bentuk satuan pendidikan formal yang meliputi Sekolah Dasar (SD), Madrasah Ibtidaiyah (MI), Sekolah Menengah Pertama (SMP), Madrasah Tsanawiyah (MTs), Sekolah Menengah Atas (SMA), Madrasah Aliyah (MA), Sekolah Menengah Kejuruan (SMK), Madrasah Aliyah Kejuruan (MAK), Sekolah Luar Biasa (SLB), Satuan Pendidikan Kerja Sama (SPK), dan satuan pendidikan formal lain yang sederajat (Kemdikbud :2019).

Kelayakan program dan/atau satuan pendidikan mengacu pada SNP. SNP adalah kriteria minimal tentang sistem pendidikan di seluruh wilayah hukum Negara Kesatuan Republik Indonesia. Oleh karena itu, SNP harus dijadikan acuan guna memetakan secara utuh profil kualitas sekolah/madrasah. Peraturan Pemerintah No. 19 Tahun 2005 tentang Standar Nasional Pendidikan pasal 2 ayat (1) menyebutkan bahwa lingkup SNP meliputi: (1) standar isi; (2) standar proses; (3) standar kompetensi lulusan; (4) standar pendidik dan tenaga kependidikan; (5) standar sarana dan prasarana; (6) standar pengelolaan; (7) standar pembiayaan; dan (8) standar penilaian pendidikan. Kegiatan akreditasi diharapkan menjadi pendorong dan dapat menciptakan suasana kondusif bagi perkembangan pendidikan dan memberikan arahan untuk melakukan penjaminan mutu sekolah/madrasah yang berkelanjutan, serta terus berusaha mencapai mutu yang diharapkan.

\section{Mutu Pendidikan}

umumnya kualitas memiliki elemen-elemen sebagi berikut: pertama, meliputi memenuhi atau melebihi harapan pelanggan, kedua, mencakup produk, jasa, manusia, proses, dan lingkungan, ketiga, merupakan kondisi yang selalu berubah. Berdasarkan elemen-elemen tersebut maka kualitas dapat didefinisikan sebagai suatu kondisi dinamis yang berhubungan dengan produk, jasa, manusia, proses dan lingkungan yang memenuhi bahkan melebihi harapan (Nurkolis :2015). Mutu pendidikan secara sederhana yaitu target khusus dari tujuan-tujuan pendidikan.34 Pada konteks pendidikan pengertian mutu mengacu pada proses pendidikan dan hasil pendidikan. Dalam proses 
pendidikan yaitu input yang meliputi bahan ajar (kognitif, afektif atau psikomotorik), metodologi, sarana sekolah, dukungan administrasi, sarana prasarana dan sumber daya lainnya serta penciptaan suasana yang kondusif. Mutu dalam konteks hasil pendidikan mengacu pada prestasi yang dicapai oleh sekolah pada setiap kurun waktu tertentu (Indra Bastian :2016).

\section{Faktor-faktor yang Mempengaruhi Kualitas Pendidikan Sekolah}

Sekolah merupakan satuan pendidikan yang bertugas menyelenggarakan pendidikan, dipandang sebagai organisasi yang didesain untuk dapat berkontribusi terhadap upaya peningkatan kualitas hidup bgi masyarakat suatu bangsa. Sebagai salah satu upaya peningkatan derajat sosial masyarakat bangsa, sekolah sebagai institusi perli dikelola, diatur, ditata dan diberdayakan agar sekolah dapat menghasilkan produk atau hasil secara optimal. Dengan kata lain, sekolah sebagai lembaga temapat penyelenggraan pendidikan, merupakan sistem yang memiliki berbagai perangkat dan unsur yang saling berkaitan yang memerlukan pemberdayaan (Nur fattah:2016).

Komponen-komponen yang perlu ditingkatkan kualitasnya sehingga menghasilkan mutu pendidikan sekolah yang baik, antara lain adalah sebagai berikut: (a) Kurikulum dan Program Pengajaran, (b) Tenaga Kependidikan, (c) Kepemimpinan, (d) Keuangan dan Pembiayaan, (e) Sarana dan Prasarana, (f) Hubungan Sekolah dengan Masyarakat.

\section{Kinerja Sekolah dalam Meningkatkan Mutu Pendidikan}

Kinerja sekolah membutuhkan standar kinerja yang dijadikan pedoman dalam peningkatan mutu sekolah. Dalam standar mutu, diperlukan pemahaman tentang konsep mutu pendidikan. Dalam konteks pendidikan banyak pendapat tentang mutu. Menurut Sallis terdapat 3 pengertian konsep mutu. Pertama, mutu sebagai konsep yang absolut (mutlak), sesuatu dikatakan bermutu jika memenuhi standar yang tertinggi dan tidak dapat diungguli, sehingga mutu dianggap sesuatu yang ideal yang tidak dapat dikompromikan, jika dikaitan dengan pendidikan mutu absolut bersifat elit karena hanya sedikit lembaga pendidikan yang dapat memberikan pendidikan dengan high quality kepada siswa dan sebagian besar siswa tidak dapat menjangkaunya(Sallis:2011). Konsep mutu Kedua, mutu dalam konsep relatif, terdapat 2 aspek yaitu mutu yang berdasarkan pada standar dan mutu yang memenuhi kebutuhan pelanggan. Selanjutnya konsep Ketiga, mutu menurut pelanggan, mutu merupakan sesuatu yang didefinisikan oleh pelanggan, yang intinya adalah kepuasan pelanggan, sejauh mana mampu memuaskan kebutuhan dan keinginan pelanggan

\section{Metode}

Penelitian ini menggunakan penelitian kualitatif dengan metode studi analisis isi dokumen (content analysis) dengan cara mengumpulkan data dari responden yang berupa dokumen-dokumen 8 standar nasional pendidikan (SNP). Serta metode studi persesi (study perception) guna mendapatkan gambaran tentang cara pandang/konsep pemikiran atau pemahaman responden. Teknik yang digunakan adalah observasi, wawancara dan dokumentasi.

\section{Hasil \\ Bagaimana Sekolah Mempersiapkan Diri Untuk Melaksanakan Akreditasi Sekolah, yang Dimulai Dengan Mengisi Data Isian Akreditasi (DIA)}

Berkaitan dengan wancara yang dilakukan, maka sejumlah pertanyaan dikemukakan oleh peneliti yakni antara lain : (1) Bagaimana sekolah memandang Akreditasi? Apa maknanya?, (2) Bagaimana sekolah menyiapkan diri menuju akreditasi?, (3) Bagaimana sekolah mengisi daftar isian akreditasi "DIA" dengan memastikan isian itu dapat dipertanggungjawabkan secara baik dan benar?, (4) Apa saja kendala dalam mempersiapkan diri (sekolah) menuju akreditasi? Ke-4 pertanyaan di atas memberi harapan adanya informasi yang konperehensif (menyeluruh) tentang kesiapan diri (sekolah) melaksanakan akreditasi yang berdampak pada jaminan mutu pendidikan di sekolah. Berikut ini merupakan hasil wawancara yang berkaitan dengan ke-4 pertanyaan di atas, yang dikemukakan oleh para informan salah satunya ditunjukan berikut ini

"Akreditasi menjadi penting bagi kami, karena akreditasi memastikan sekolah berjalan memenuhi aturan yang berlaku serta standar-standar pendidikan yang seharusnya dilakukan. Sekolah ini sejak tahun 2011 sampai 2019 baru pernah dilakukan akreditasi oleh Badan Akreditasi Nasional, perjalanan panjang ini kami maknai sebagai upaya kerja keras semua pihak mempersiapkan diri menuju akreditasi tahun 2019. Walaupun kepala sekolah sejak tahun 2011 sampai 2018 belum sama sekali mengajukan diri 
untuk sekolah ini diakreditasi, dan saya juga tidak tahu mengapa hal itu terjadi. Namun sejak saya menjadi kepala sekolah 1 tahun ini (2018-2019), saya kira sekolah ini sudah layak untuk melaksanakan akreditasi. Dalam mempersiapkan diri untuk menuju akreditasi sekolah, saya harus menyiapkan tim kerja untuk mensukseskan akreditasi. Tim dibentuk dengan susunan yang terdiri dari ketua Tim dan anggota yang sesuai dengan 8 standar nasional pendidikan. Dan saya sebagai penasehat dan penanggung jawabnya. Berkaitan dengan Data isian akreditasi (DIA) sebagai prasyarat sekolah telah mempersiapkan diri untuk melakukan akreditasi, diisi secara online oleh operator sekolah yang memastikan semua soal/pertanyaan/pernyataan sudah dengan benar diisi dan dipastikan sudah sesuai dengan kenyataan di sekolah. Kalau ditanya apa saja kendala dalam mempersiapkan diri (sekolah) menuju akreditasi, menurut saya, sejak lama sekolah ini berbenah dari berbagai kekurangan yang ada untuk menyesuaikan dengan 8 standar pendidikan tersebut, dan sampai tahun 2019. Jadi saya kira pada standar sarana prasaranalah yang belum maksimal kami miliki seperti infocus sebagai media pembelajarannya (Ibu N.B. Nikijuluw :wawancara).

\section{Adakah Rekomendasi Dari Para Asesor Yang Melakukan Visitasi Terhadap 8 Standar Pendidikan?}

Berkaitan dengan indikator di atas, maka dalam wawancara ini, ada sejumlah pertanyaan antara lain : (1) Apa saja catatan/rekomendasi dari para Asesor saat melakukan Akreditasi di sekolah Anda?, (2) Bagaimana Anda menindaklanjuti catatan rekomendasi tersebut untuk kedepannya dapat lebih baik?. Berikut ini merupakan hasil wawancara yang berkaitan dengan ke-2 pertanyaan di atas, yang dikemukakan oleh para informan yang salah satunya dikutip di bawah ini: (wawancara dengan Ibu R. K. Pelupessy). "Karena kami baru saja melaksanakan akreditasi pada Juli 2019, maka ada sejumlah catatan rekomendasi yang dijelaskan oleh para asesor untuk dijadikan perbaikan ke depannya. Catatan secara tertulis tidak langsung diberikan kepada kami, namun hanya lewat penjelasan tersebut kami diberi tahu hal-hal yang perlu diperhatikan kedepannya. Perbaikan memiliki saling berkaitan antara standar satu dengan standar yang lain, untuk itu sebagai kepala sekolah saya lebih mendorong untuk kerja-kerja bersama demi menindaklanjuti berbagai rekomendasi para asesor tersebut. Yang berkaitan dengan penggunaan anggaran yang besar untuk membangun dan pengadaan fasilitas yang besar biayayanya, belum langsung dilaksanakan saat ini, dan tetap akan diusahakan untuk dibangun kedepan. Namun yang dapat dijangkau oleh anggaran sekolah dapat langsung diupayakan terealisasi saat ini, misalnya peralatan olah raga, peralatan UKS, peralatan lab IPA dan pengecatan sejumlah ruangan, dan membangun 1 jalu koridor"( Wawancara dengan kepala sekolah SMP Negeri 4 Saparua ( Ibu R. K. Pelupessy).

\section{Upaya-Upaya Yang Dilakukan Untuk Dapat} Menjamin Mutu Pendidikan Yang Berkualitas, Serta Faktor Apa Saja Yang Menjadi Penghambatnya.

Hal ini menjadi evaluasi diri (sekolah) terhadap 8 standar nasional pendidikan (8 SNP) sudah memenuhi atau belum. Untuk itu, dibawah ini, disajikan kedalam tabel muatan 8 standar nasional pendidikan (8 SNP) yang dikaji berdasarkan Dokumen data isian akreditasi (DIA) yang dimiliki oleh sekolah sekaligus hasil wawancara dengan para informan, dengan demikian akan memberikan gambaran tentang setiap standar yang dicapai oleh sekolah, sehingga dapat dijadikan evaluasi menyeluruh terhadap pemenuhan standar nasional pendidikan oleh sekolah-sekolah tersebut. Berikut ini ditunjukan data 8 SNP yang disajikan dalam tabel, namun yang ditunjukan hanya 2 dari 8 standar yang dinilai dari dokumen DIA sekolah yang diteliti seperti :

Tabel 3.1.

\section{Penilaian Standar Isi Mengacu dari Dokumen Data Isian Akreditasi (DIA) Yang Dimiliki Oleh Sekolah}

\begin{tabular}{|c|c|c|c|c|}
\hline No & Nama Sekolah & $\begin{array}{c}\text { Nilai Standar } \\
\text { Isi }\end{array}$ & Item Instrumen & Keterangan \\
\hline 1 & SMP Negeri 1 Saparua & 95 & No 1,4 dan 9 & Perlu Perbaikan \\
\hline 2 & SMP Negeri 3 Saparua & 95 & No 6 dan 9 & Perlu Perbaikan \\
\hline 3 & SMP Negeri 4 Saparua & 89 & Item, $1,4,8$ dan 9 & Perlu Perbaikan \\
\hline 4 & SMP Negeri 5 Saparua & 95 & No 5 dan 8 & Perlu Perbaikan \\
\hline 5 & SMP Negeri 6 Saparua & 100 & Tidak ada & Sudah Baik \\
\hline 6 & SMP Kristen Saparua & 92 & No 4, dan 6 & Perlu Perbaikan \\
\hline
\end{tabular}


Tabel 3.3.

\section{Penilaian Standar Kompetensi Lulusan (SKL) Mengacu dari Dokumen Data Isian Akreditasi (DIA) Yang Dimiliki Oleh Sekolah}

\begin{tabular}{|c|c|c|c|c|}
\hline$N_{0}$ & Nama Sekolalah & Nillai SKL & Item Perbaikan & Keterangan \\
\hline 1 & SMP Neger 1 Saparua & 85 & No $33,34,36,37$ & Perlu Perboikizan \\
\hline 2 & SMP Negeri 3 Saparua & 86 & No $32,33,34,37$ & Perlu Perboiktan \\
\hline 3 & S.P. Negeri 4 Saparua & 79 & No $32,33,34,37$ & Peflu Perboilizan \\
\hline 4 & SMP Negeri I Saparua & 94 & No 034,36 & Perlu Perboilikan \\
\hline 5 & SIP Neger 6 Saparua & 96 & No 033,37 & Perlu Perboilizan \\
\hline 6 & SMPP Kristen Saparua & 91 & No $33,34,36$ & Perlu Perboilizan \\
\hline
\end{tabular}

Dan berdasarkan hasil wawancara yang berkaitan dengan pertanyaan (1) apa saja upaya yang dilakukan untuk menjamin mutu pendidikan berdasarkan 8 SNP di sekolah anda dan (2) apakah terdapat faktor yang mengambat sekolah anda dalam mewujudkan upaya tersebut?. Yang dikemukakan oleh para informan yang salah satu pernyataan informan dikutip di bawah ini: (wawancara dengan Bpk A. H. Ritawaemahu). "Saya kira, upaya-upaya yang dilakukan untuk menjamin mutu pendidikan berdasarkan 8 SNP di sekolah ini, sementara dan terus kami kerjakan kedepannya, tidak ada hentinya. Pada aspek kurikulum 2013 kami terus melihat bagaimana kelengkapan perangkat pembelajaran yang harus sesuai dengan tuntutan kurikulum, penilaian-penilaian yang ada, buku-buku yang diperlukan. Sedangkan dalam pembelajaran siswalah yang harus aktif membangun pengetahuannya, guru yang memfasilitasi, dan membimbing siswa, maka oleh karena itu guru dilibatkan dalam kegiatan-kegiatan keilmiahan seperti seminar atau workshop di Dinas Pendidikan Kabupaten Maluku Tengah. Bagi siswa didorong melakukan praktek-praktek baik dalam bentuk olah raga maupun praktek di laboratorium, memberikan tugas-tugas proyek kelompok. Selain itu siswa dilibatkan dalam kegiatan-kegiatan kepramukaan, osis dan UKS, maupun pembinaan prestasi bagi yang berbakat dan cerdas. Sudah tentu administrasi penting untuk dilakukan oleh para tata usaha, baik tata usaha di kantor maupun tata usaha yang bekerja pada unit perpustakaan dan lainnya, mekanisme kerja dan pelaporan pertanggung jawab perlu dilakukan sesuai tenggat waktu yang ditentukan. Sekolah dikelola dengan prinsip-prinsip demokratis yakni dari dan untuk kebaikan bersama. Semua pihak menyampaikan ide, pemikiran dan bahkan kritik sehingga perlu dievaluasi secara bersama, diputuskan dengan kesepakatan bersama begitulah manajemen berbasis sekolah. Dan pada standar sarana dan prasarana maka hal ini berhubungan dengan pembiayaan, ada bangunan baru untuk laboratorium komputer karena sekolah ini berencana menyelenggarakan UN berbasis komputer (UNBK) Tahun depan, sehingga di tahun ini ada sekitar 3040 komputer yang diperoleh sekolah. Kalau ditanya apakah terdapat faktor yang mengambat sekolah anda dalam mewujudkan upaya tersebut?, menurut saya adalah tidak terlalu banyak hambatannya. Semua guru mau bekerja keras, namun seringkali terkendala biaya. Kami punya salah satu hambatan yaitu jalan masuk ke sekolah yang belum memiliki jalan setapak sehingga seringkali licin untuk sampai di sekolah, dan sudah dijanjikan oleh Anggota Legislatif dan Pemerintah Kabupaten namun sampai saat ini belum terealisir" (Wawancara dengan kepala sekolah SMP Negeri 3 Saparua (Bpk A. H. Ritawaemahu).

\section{Pembahasan}

\section{Bagaimana Sekolah Mempersiapkan Diri Untuk Melaksanakan Akreditasi Sekolah, Yang Dimulai Dengan Mengisi Data Isian Akreditasi "DIA"?}

(1) Akreditasi sekolah memiliki makna yang penting bagi kepala sekolah, karena sebagai penanggung jawab penyelenggaran penddikan di sekolah, ia akan memastikan semua program pendidikan akan mengarah kepada terpenuhinya 8 standar nasional pendidikan, dengan tetap menyesuaikan dengan kebijakan pendidikan dan program pemerintah dibidang pendidikan. (2) Untuk itu berkaitan dengan tahapan akreditasi maka sekolah sudah harus membentuk tim kerja atau tim akreditasi yang bekerja demi pemenuhan standar nasional pendidikan (8 SNP) tersebut. Kerja-kerja tim akan mengarah pada mempersiapkan dokumen pendukung akreditasi serta menginfentarisir fasilitas sarana dan prasarana yang merupakan tuntutan akreditasi sebagai syarat standar sarana dan prasarana, sehingga oleh pimpinan sekolah perlu di adakan, direnovasi, atau dibangun yang baru. Semua kerja keras tim ini akan berdampak pada penilaian akreditasi sekolah apakah sudah sesuai dan memastikan dapat terakreditasi dengan penilaian A, $\mathrm{B}$ atau $\mathrm{C}$, bahkan tidak terakreditasi dengan 
memperoleh penilaian D dan E. (3) Kepala sekolah juga melakukan pengisian data akreditasi (DIA) secara online, suatu instrumen penilaian terhadap kesiapan sekolah dalam mengikuti akreditasi. Sebagai kepala sekolah akan memiliki pilihan yang tepat dalam mengisi akreditasi seperti mempersiapkan kebutuhan akreditasi selanjutnya mengisi DIA, juga dapat melakukan pengisian DIA dan memastikan sekolah dapat mengusahakan untuk terpenuhi sebelum tim akreditasi melakukan validasi di lapangan (akreditasi) sejauh mana sekolah telah siap akreditasi. Kendala-kendala tersebut sudah dipastikan akan mempengaruhi penilaian asesor ketika melakukan akreditasi. Untuk itu kepala sekolah dan tim kerja atau tim akreditasi sekolah sedari awal sudah memetakan berbagai kekurangan dan kelemahan yang berhubungan dengan 8 standar penilaian tersebut dan dengan upaya yang maksimal dapat mengusahakan pemenuhan kebutuhan tersebut. Suatu upaya yang perlu mendapat dukungan dari semua komponen sekolah (guru, siswa, komite sekolah dan orang tua atau masyarakat).

\section{Adakah Rekomendasi Dari Para Asesor Yang Melakukan Visitasi Terhadap 8 Standar Pendidikan?}

(1) Terdapat catatan rekomendasi yang disampaikan oleh para asesor sebagai bagian dari proses klarifikasi atas data yang ditemukan dilapangan (sekolah), sehingga dalam penilaian tersebut para asesor beranggapan bahwa penting memberi masukan dan mengoreksi hal-hal yang tidak berjalan sesuai tuntutan 8 standar nasional pendidikan (8 SNP) yang terjadi di sekolah sasaran akreditasi. Agar supaya kedepannya sekolah dapat lebih baik lagi dalam mempersiapkan diri (sekolah) menuju akreditasi yang bermutu. (2) Berbagai masukan melalui catatan rekomendasi oleh para asesor ini sangat membantu sekolah dalam memahami kekurangan dan kelemahan yang ada. Membantu sekolah untuk mengetahui dengan baik, berbagai hal yang sesuai dengan tuntutan instrumen akreditasi sekolah, sehingga dengan pengetahuan yang baik tersebut, akan bermanfaat untuk mengupayakan pemenuhan terhadap kekurangan dan kelemahan tersebut. Seringkali sekolah sudah melakukan program sekolah, hanya melaksanakan dan tanpa pendokumentasian yang baik, maka program tersebut tidak memiliki bukti apa-apa, sehingga kegiatan ini dianggap tidak terjadi karena tidak memiliki bukti yang valid. Untuk itu sebagai rekomendasi untuk kiranya dapat ditindaklanjuti dengan penuh tanggung jawab, maka sudah tentu sekolah seharusnya menindaklanjutinya dengan mengupayakan agar berbagai rekomendasi tersebut dapat dipenuhi dengan baik. (3) Sekolah mengupayakan berbagai cara antara lain yang berkaitan dengan tanggung jawab guru, tata usaha, dan kepala sekolah seperti minimnya dokumendokumen sekolah, maka mereka harus segera mengadakannya, dan kedepannya cara kerjanya mesti memastikan ada dukungan dokumentasi yang baik terhadap tugas-tugas mereka. Sedangkan yang berkaitan dengan upaya pembangunan fisik bangunan dan faslitas penunjang lainnya, maka harus disesuaikan dengan kemampuan keuangan sekolah, sehingga ada fasilitas yang dapat langsung dipenuhi, dan ada sarana prasarana yang membutuhkan waktu yang agak lama untuk dibangun atau direnovasi kembali.

\section{Upaya-Upaya Yang Dilakukan Untuk Dapat Menjamin Mutu Pendidikan Yang Berkualitas}

(1) Pengembangan kapasitas guru, baik melalui keterlibatan pada kegiatan-kegiatan ilmiah, juga diikutsertakan dalam uji kompetensi guru. Pengembangan kapasitas guru juga terkait dengan penguasaan bidang keilmuan serta penguasaan pada tuntutan kurikulum 2013 dengan berbagai revisi terbaru. Guru harus menghasilkan dokumen perangkat pembelajaran yang baik sesuai tuntutan K13, sampai dengan lembaran penilaian kompetensi siswa. (2) Mendorong berbagai pihak bekerja keras mengupayakan pembangunan sekolah seperti pembangunan ruang kelas, ruang laboratorium IPA, laboratorium komputer, dan juga ruangan untuk kepala sekolah dan guru, dan hal itu sementara dibangun di tahun ini maupun di tahun depan. (3) Memastikan Tata administrasi sekolah terus diperbaiki sehingga kearsipan sekolah dapat mendukung pengembangan pendidikan yang melayani semua siswa. Tenaga tata usaha pun diikutkan dalam pelatihan-pelatihan, juga tenaga perpustakaan agar dapat mengelola pelayanan perpustakaan dengan baik. (4) Manajemen sekolah dilakukan dari dan untuk kebaikan bersama, maka berbagai ide, gagasan dan pemikiran membangun 
serta kritik dari siapapun, akan dianggap sebagai proses yang baik dalam tujuan untuk memajukan sekolah. (5) Pada aspek siswa, dijadikan fokus pengembangan karakter, kepribadian dan peningkatan prestasi. Bentuk kegiatan kesiswaan dilakukan dalam bentuk intrakurikuler, ekstrakurikuler dan peningkatan prestasi serta bakat yang dimiliki siswa. Sehingga turut dilibatkan dalam berbagai lomba cerdas cermat tingkat kabupaten tetapi juga tingkat provinsi, selain itu mengikuti pertandingan atau lomba keolahragaan yang dapat diikuti pada tingkat lokal maupun nasional. (6) Pembiayaan diatur agar anggaran dapat disesuaikan dengan pemenuhan kebutuhan baik yang sudah diprioritaskan maupun dalam tahapan realisasi anggaran. Maka terlihat dalam pembiyaan secara bertahap yang sesuai kebutuhan siswa dalam belajar di kelas. Serta keterlibatan sekolah dalam berbagai kegiatan kemasyarakatan. (7) Melibatkan masyarakat dalam kegiatan-kegiatan sekolah seperti siswa taat berlalu lintas, dokter cilik, sehingga ada petugas polisi yang datang untuk membina siswa untuk memahami peraturan lalu lintas, juga para tenaga puskesmas yang mensosialisasikan hidup yang sehat.

\section{Faktor Apa Saja Yang Menjadi Penghambat Dalam Meningkatkan Mutu Pendidikan Melalui Akreditasi Sekolah?}

Memperhatikan hasil penelitian yang telah dipaparkan di atas, maka dapat dijelaskan bahwa upaya yang sudah dilakukan, tidak luput dari hal-hal yang dapat turut menghambat pencapaianpencapaian tersebut. Seperti :

1) Tidak adanya semangat dari sebagian guru, guru tidak termotivasi untuk melaksanakan tugasnya dengan target waktu. Guru acuh dengan perkembangan yang ada, dan tidak mau meningkatkan kemampuan keilmuannya sehingga ketika didorong untuk mengikuti UKG atau mengambil kualifikasi ilmu ke jenjang S1, guru tidak mau. Bagi guru-guru yang sudah senior dan hampir pensiun, mereka merasa kesulitan dalam menyesuikan dengan tuntutan kurikulum yang ada, apalagi harus menggunakan komputer untuk bekerja, dan tuntutan menggunakan komputer dalam mengajar di kelas, hal ini membuat mereka sudah tidak mau menyesuikan lagi dengan perkembangan yang ada.

2) Sedangkan disisi lain faktor minimnya anggaran yang turut menjadi penghambat dalam mendukung berbagai program kerja tahunan dan jangka menengah. Sehingga anggaran sudah semestinya dipakai dengan lebih efisien dan efektif. Untuk itulah maka bentuk pembiayaan yang menggunakan anggaran yang besar maka akan diusahakan melalui jalur lainnya yang tidak melanggar aturan. Namun hal ini sudah tentu akan memakan waktu yang cukup lama.

\section{Simpulan}

Kesimpulan yang dapat penulis berikan adalah :

1. Akreditasi memiliki makna yang penting bagi sekolah. Dan di setiap tahapan akreditasi sekolah perlu adanya tim kerja atau tim akreditasi yang bekerja demi pemenuhan standar nasional pendidikan (8 SNP) di sekolah. Dengan mempersiapkan diri (sekolah) menuju akreditasi sekolah secara baik, maka tahapan selanjutnya sekolah harus melakukan pengisian data akreditasi (DIA) secara online pada SISPENA BAN S/M, suatu instrumen penilaian terhadap kesiapan sekolah dalam mengikuti akreditasi.

2. Sejumlah catatan rekomendasi yang disampaikan oleh para asesor sebagai bagian dari proses klarifikasi atas data yang ditemukan dilapangan (sekolah), hal ini sangat membantu sekolah dalam memahami kekurangan dan kelemahan yang ada. Membantu sekolah untuk mengetahui dengan baik, semua tuntutan instrumen akreditasi sekolah. Serta sebagai rekomendasi maka seharusnya ditindaklanjuti dengan penuh tanggung jawab, dengan mengupayakan agar kedepannya semakin baik lagi.

3. Upaya-upaya yang dilakukan untuk dapat menjamin mutu pendidikan yang berkualitas oleh sekolah adalah yang sesuai dengan tuntutan 8 standar nasional pendidikan seperti Pengembangan kapasitas guru dan tenaga kependidikan, mengadakan pembangunan sekolah berupa sarana dan prasarana serta fasilitas penunjang lainnya, menata 
administrasi secara profesional, Manajemen sekolah secara demokratis dikelola untuk kepentingan dan kebaikan semua pihak, fokus pengembangan karakter, kepribadian dan peningkatan prestasi siswa. Pembiayaan yang diatur sesuai kebutuhan di sekolah, serta terlibat dalam kegiatan di tengah-tengah masyarakat, maupun sebaliknya melibatkan masyarakat dalam kegiatan-kegiatan di sekolah.

4. Adanya Guru yang tidak bersemangan, guru tidak termotivasi untuk melaksanakan tugasnya dengan target waktu. Guru acuh dengan perkembangan yang ada, dan tidak mau meningkatkan kemampuan keilmuannya. Bagi guru-guru yang sudah senior dan hampir pensiun, mereka merasa kesulitan dalam menyesuikan dengan tuntutan kurikulum yang ada. Serta disisi lain minimnya anggaran turut menjadi penghambat dalam mendukung berbagai program kerja tahunan dan jangka menengah.

\section{Saran Dan Rekomendasi}

Adapun saran yang diharapakan adalah

1. Kepala Sekolah, agar terus memfasilitasi kegiatan pengembangan kapsitas guru melalui workshop, seminar, diklat, sosialisasi, dll, agar guru terus mengikuti perkembangan pendidikan dan dalam tugas profesionalitasnya, dapat meningkatkan mutu pendidikan di sekolah masing-masing.

2. Untuk Guru, agar terus membangun jaringan kerja sama, terus berkolaborasi dalam kelompok- kelompok musyawarah guru (MGMP), kelompok kerja guru (KKG), agar nantinya berperan aktif dalam memenuhi berbagai kebutuhan standar isi, proses dan kelulusan yang akhirnya dapat meningkatkan mutu pendidikan di sekolah.

3. Dinas Pendidikan terkait, agar dalam fungsi pengawasannya, dapat mencari solusi, membantu permasalahan yang dialami sekolah yang belum meningkatkan akreditasinya, sehingga dapat memacu kinerja sekolah dalam upaya memenuhi standar mutu pendidikan di sekolah.

\section{Ucapan Terima Kasih}

Pada kesempatan ini, terimakasih saya ucapkan kepada redaktur yang telah memberikan masukan yang berharga sehingga tulisan ini dapat disajikan di jurnal Institutio. Terimakasih juga saya ucapkan kepada seluruh dewan redaksi jurnal Institutio yang sudah memberikan ruang diskusi. Semoga bantuan dan dukungannya mendapatkan balasan yang sebanyak-banyaknya dari Tuhan kita Yesus Kristus, Amin.

\section{Pustaka Acuan}

Abdul Malik, dkk. (2019) Pedoman Akreditasi Sekolah/Madrasah 2019. Badan Akreditasi Nasional S/M (BAN S/M). Jakarta

Akdon. (2011). Strategic Management For Educational Management (Manajemen Strategik untuk Manajemen Pendidikan) Bandung: Alfabeta,.

B. Suryosubroto, (2016) Manajemen Pendidikan di Sekolah, Jakarta: Rineka Cipta

Chu, Reynolds, Tavares, Notari, \& Lee, (2017). 21st Century Skills Development Through Inquiry-Based Learning, Springer

Depdiknas, (2008). Panduan Pelaksanaan Pembinaan SMP Standar Nasional (SSN).

Depdiknas, (2009). Kebijakan dan Pedoman Akreditasi SekolahSekolah/Madrasah, Jakarta : BAN $\mathrm{S} / \mathrm{M}$

Hendarman. (2014). Kendala-Kendala Pelaksanaan Evaluasi Diri Sekolah (EDS). Jurnal Pendidikan dan Kebudayaan, Program Pascasarjana. Universitas Pakuan Bogor dari http://jurnaldikbud.kemdikbud. go.id/index.php/jpnk/article/viewFile/ $134 / 124$

Indra Bastian, (2016). Akuntansi Pendidikan, Jakarta: Erlangga 
Kemdikbud. (2019) Pedoman Akreditasi Sekolah/Masdrasah. Jakarta. BAN $\mathrm{S} / \mathrm{M}$

Moeheriono, (2018). Pengukuran Kinerja Berbasis Kompetensi. Jakarta: Raja Grafindo Persada

Miles. B. \& Huberman. M. (1992) Analisis Data Kualitatif. Jakarta. UI Press.

Mulyasa, E . Dr. M. Pd , (2003) Manajemen Berbasis Sekolah ( konsep, strategi dan implementasi), Bandung: PT. Remaja Rosdakarya

Nanang Fattah, (2016) Manajemen Berbasis Sekolah, Bandung: Andira

Nurkolis, M. M, (2015) Manajemen Berbasis Sekolah: Teori, Model, dan Aplikasi, Jakarta: Grasindo,

Pearce, Robinson, (1997). Manajemen Strategik, Formulasi Implementasi, dan Pengendalian. Jilid satu. Jakarta: Binarupa Aksara

Sallis, Edward. (2011) Manajemen Mutu Terpadu Pendidikan. Jogjakarta: IRCiSoD.

Soedjono, (2012). Pengembangan Model Penyelenggaraan Akreditasi Sekolah Menegah Atas di Kota Semarang, PPs Universitas Negeri Semarang. Jurnal Manajemen Pendidikan Vo.1 No. 2. 2012.

Sumber:http://download.portalgarud a.org/article. (online), Diakses 12 Juni 2019, Pukul 10.00

Sukmadinata, Nana Syaodi. (2012) Metode Penelitian Pendidikan. Bandung: PT. Remaja Rosdakarya

Website

https://www.kabartimurnews.com/2019/03/29/sek olah-tak-lolos-akreditasi-pusathentikan-dana-bos/

https://kumparan.com/ambonnesia/223-sekolah-dimaluku-masih-terakreditasi-c-
http://dapodikdasmen.data.kemdikbud.go.id/SE\%20

Kualitas\%20Data\%20Pokok\%20Pendidikan\%20Das ar\%20dan\%20Menengah.pdf 